Ferdinand Z. Guintu, MD

Antonio H. Chua, MD

Department of Otorhinolaryngology Head and Neck Surgery

Jose R. Reyes Memorial Medical Center
Correspondence: Dr. Ferdinand Z. Guintu Department of Otorhinolaryngology Head and Neck Surgery

Jose R. Reyes Memorial Medical Center

San Lazaro Compound, Rizal Avenue

Sta. Cruz, Manila 1003

Philippines

Phone: (632) 7436921 ;

(632) 7119491 local 320; (632) 9228978070

Email: ferdinandguintu@yahoo.com

Reprints will not be available from the author.

The authors declared that this represents original material that is not being considered for publication or has not yet been published or accepted for publication elsewhere, in full or in part, in print or electronic media; that the manuscript has been read and approved by all the authors, that the requirements for authorship have been met by each author, and that each author believes that the manuscript represents honest work.

Disclosures: The authors signed disclosures that there are no financial or other (including personal) relationships, intellectual passion, political or religious beliefs, and institutional affiliations that might lead to conflict of interest.

Presented at the Philippine Society of Otolaryngology - Head and Neck Surgery Analytical Research Contest (1st Place), October 11, 2012, Nathan Hall, GSK Bldg, Chino Roces Avenue, Makati City, Philippines

Department of Health 1st Research Forum (2nd Place), National Hospital Week Celebration 2012 on August 9, 2012 at Dr. Enrique T. Ona Auditorium, Diagnostic Center, National Kidney and Transplant Institute, East Avenue, Quezon City, Philippines Annual Residents Research Paper 2012 (3rd Place), Jose R. Reyes Memorial Medical Center, Rizal Avenue, Sta Cruz, Manila, Philippines

\section{Effectivity of Guava Leaves (Psidium guajava) as Mouthwash for Patients with Aphthous Ulcers}

\author{
ABSTRACT \\ Objective: To determine whether Psidium guajava leaves mouthwash is effective in the \\ management of patients with aphthous ulcers. \\ Methods:
}

Design: Randomized prospective open label clinical study

Setting: Tertiary Government Training Hospital

Subjects: Thirty two patients diagnosed with aphthous ulcers were randomly divided into two groups, a treatment group using prepared guava leaves mouthwash, and a control group using isotonic sodium chloride solution mouthwash given thrice a day for seven days. Patients were evaluated using a 10-point Visual Analog Scale. The sizes of the aphthous ulcers were measured using a caliper, and compared on Day 1 and Day 7 for both treatment and control groups. Results were subjected to statistical analysis using T-test, Mann-Whitney $\mathrm{U}$ test and Fisher Exact test.

Results: Comparison of VAS scores of guava treatment and NSS control groups showed that there were no differences in pain experienced on Days 1 and 2. However, the VAS scores from Day 3 to 7 had $p$ values ranging from $0.02-0.0001$ which showed significant differences in resolution of pain. There was statistically significant marked improvement of pain symptoms as early as three days post-treatment among patients who were administered guava leaves mouthwash. Complete resolution of aphthous ulcers in $75 \%$ of the study group was observed on Day 7 . Mean ulcer size post-treatment with guava gargle was $0.25 \mathrm{~mm}$ compared to $0.75 \mathrm{~mm}$ for NSS gargle. The mean size difference at day 7 was $1.44 \mathrm{~mm}$ for the guava treatment group and $0.88 \mathrm{~mm}$ for the NSS control group. There was a statistically significant faster resolution of ulcer size on day 7 in $16 / 16$ or $100 \%$ of patients in the treatment group compared with only $10 / 16$ or $62.5 \%$ of patients in the control group. Patients who were administered guava leaves mouthwash generally fared better than those administered isotonic sodium chloride solution.

Conclusion: Guava leaves mouthwash was effective for aphthous ulcers in terms of reduction of symptoms of pain and faster reduction of ulcer size. Further clinical trials comparing this mouthwash against other treatment options are recommended.

Keywords: guava leaves (Psidium guajava), aphthous ulcers, mouthwash 
Herbal medicine is one of the main modalities in traditional as well as complementary and alternative medicine; and is increasingly acknowledged due to the extensive use of herbal remedies among the general population in developed and developing countries worldwide.'

"Bayabas" or guava (Psidium guajava) is a plant of the family Myrtaceae.' In the backyards of most Filipino homes in the rural countryside, this plant is commonly seen and grown because of its many uses as fruit and as traditional remedy to treat various ailments. Research studies have shown that almost all of the parts of this plant have medicinal qualities, making it one of the most popular therapeutic plants in the Philippines and one of the approved medicinal plants of Department of Health. ${ }^{2}$

Guava (Psidium guajava) is a small tree that can grow up to 3 meters tall. The fruit, bark and leaves are used as herbal medicine. A decoction of its leaves is recognized for its effectiveness in curing several ailments, including the treatment of chronic diarrhea and gastroenteritis. The most common use of the leaves is for cleaning and disinfecting wounds by rinsing the afflicted area with a decoction of the leaves. It can also be used as a wash for uterine and vaginal problems, and is good for ulcers. Leaf decoction may also be used as mouthwash. ${ }^{2}$ Psidium guajava has also been used for the management of various diseases like toothache, sore throat, and inflamed gums. ${ }^{3}$

Aphthous ulcers are the most common oral mucosal disorder. ${ }^{4}$ These are acute and extremely painful mouth ulcers usually involving nonkeratinized oral mucosal sites. Aphthous ulcers are usually round with a slightly raised margin and erythematous halo ${ }^{4}$ and may be classified into minor, major and herpetiform. ${ }^{5}$ Approximately 80 percent of patients have minor aphthous ulcers. ${ }^{5}$ These are 2 to $8 \mathrm{~mm}$ in diameter affecting nonkeratinized mucosa such as the labial and buccal mucosa and the floor of mouth or the ventral surface of the tongue. Much less common are major aphthous ulcers, larger than minor ulcers, often $1 \mathrm{~cm}$ or more in diameter. ${ }^{5} \mathrm{~A}$ third and even less common variety is termed "herpetiform ulceration" and comprises ulcers that are initially multiple and pinpoint. ${ }^{5}$ These may interfere with eating, drinking and swallowing. Several causes have been implicated: local trauma, viral infection, systemic causes, poor oral hygiene, stress and others. Although patients have spontaneous healing within 10-14 days, no specific treatment for aphthous ulcers is yet available. ${ }^{4,6}$ The goals of aphthous ulcer treatment have been to control pain and promote healing. ${ }^{7}$ Mouthwashes may also help. ${ }^{8}$

This study was designed to determine whether Psidium guajava leaves mouthwash is effective in the management of patients with aphthous ulcers. Specifically, we sought to determine whether Psidium guajava mouthwash as compared to isotonic saline mouthwash, decreases the symptoms of pain in patients with aphthous ulcers; and to assess whether Psidium guajava mouthwash, as compared to isotonic saline mouthwash, will hasten aphthous ulcer resolution.

\section{METHODS}

Study design: Randomized Prospective open label clinical study Setting: Tertiary government training hospital

Study population: Patients aged 10 years old and above, diagnosed with minor aphthous ulcers in our hospital outpatient department from July to December 2011, who were able to understand and give written informed consent (or assent) and report adverse events were considered.

Excluded were those with major and herpetiform aphthous ulcers; those with an oral cavity mass with superimposed ulcer where malignancy could not be totally ruled out; those with co-morbid conditions, uncontrolled metabolic conditions or psychiatric conditions; and pregnant patients.

Thirty-two patients meeting the inclusion and exclusion criteria and who gave informed consent (or assent, where consent was obtained from the parent or legal guardian in those $<18$ years of age) were included in the study, fulfilling the pre-determined sample size.

\section{Patient Procedure:}

Subjects were divided into a treatment group and control group using a randomization table. Treatment group patients used the Psidium guajava leaves mouthwash. They were each given prepared guava mouthwash solution to gargle and instructed to gargle $250 \mathrm{ml}$ of the solution for 3 minutes using any watch or clock thrice a day for one week. Control group patients used isotonic sodium chloride solution (NSS) mouthwash. They were each given prepared NSS mouthwash and instructed to gargle $250 \mathrm{ml}$ for 3 minutes using any watch or clock thrice a day for one week. Patients were asked on Day 7 if there was any adverse reaction to the gargle.

Treatment and control groups self-accomplished aphthous ulcer pain scoring daily using a 10-point Visual Analog Scale (VAS) where 0 indicated no symptoms and 10 indicated worst symptoms for the entire treatment phase, beginning with a baseline in clinic on Day 1. Blank VAS scales (Figure 1) were given to each participant and collected after 7 days.

Aphthous ulcer sizes for both treatment and control groups were also measured and recorded using one caliper (Aesculap, Tuttlingen, Germany) pre- treatment (day 1) and post-treatment (day 7) by a blinded outpatient resident on duty. 


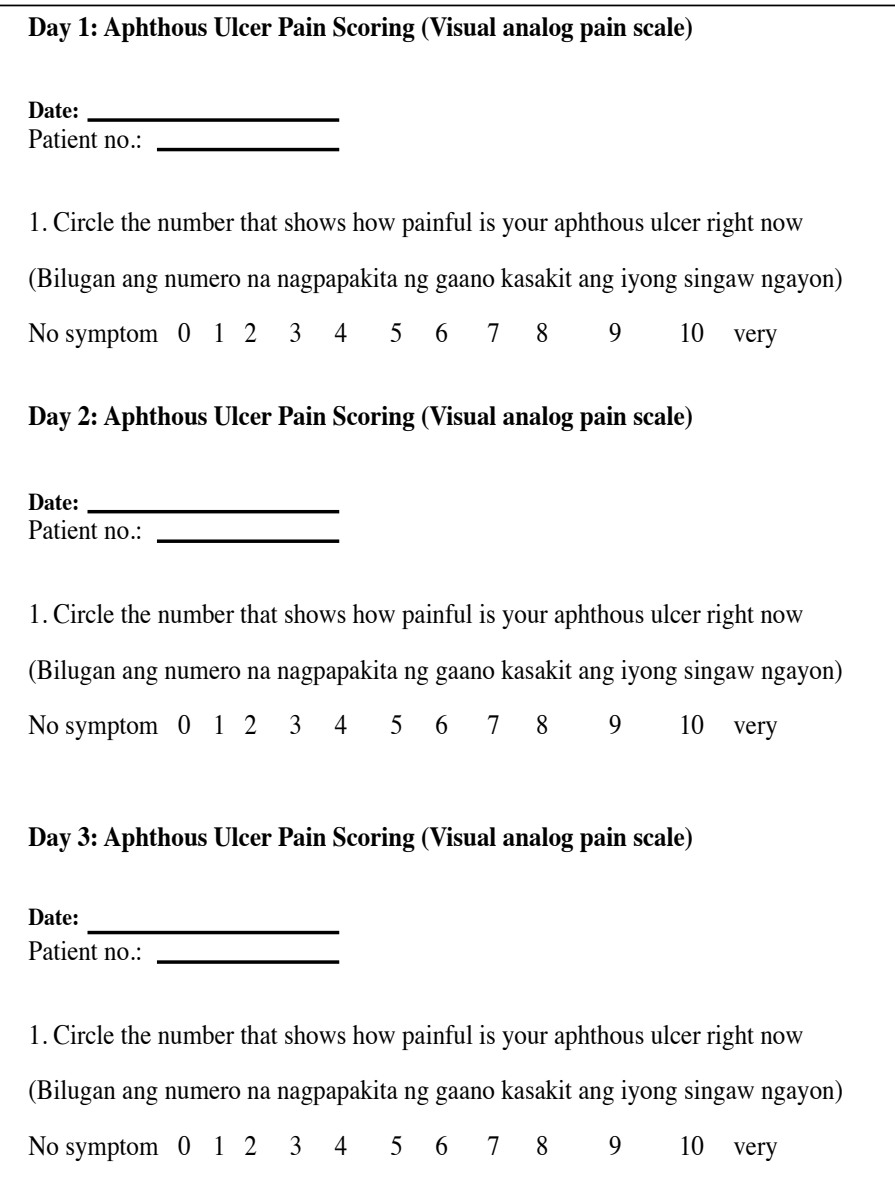

Figure 1. Sample blank visual analog scale

\section{Preparation of Materials}

Fresh guava leaves were gathered from Pampanga province and verified by a local biologist. The guava leaves were washed with water, and batches of $200 \mathrm{gm}$ of guava leaves were boiled in $750 \mathrm{ml}$ of water for 8 to 10 minutes. The boiled leaves were removed and the solution was cooled and transferred into sealed 1 liter clean clear plastic containers and placed in the refrigerator. Commercially-available Isotonic Saline Solution (Euro-med, Cavite) were transferred into sealed clean clear plastic containers for the control group.

\section{Data management and analysis}

Outcome measures were based on comparison of the two groups after 7 days. Primary outcome measures were reduction in the median VAS pain score and reduction in the median ulcer size. Summary measures (mean and percentage) were also determined for the demographic distribution of study participants and other outcomes.
The null hypotheses tested were as follows:

1. There is no significant difference in VAS scores for pain between patients using guava mouthwash and patients using isotonic sodium chloride solution mouthwash.

2. There is no significant difference in size of the aphthous ulcer between patients using guava mouthwash and patients using isotonic sodium chloride solution mouthwash.

All data were encoded and tallied in SPSS version 10 for windows (IBM, New York, USA). Descriptive statistics were generated for all variables. For nominal data, frequencies and percentages were computed. For numerical data, mean $\pm \mathrm{SD}$ were generated. Analysis of the different variables was done using the T-test, Mann Whitney $U$ test and Fisher Exact test.

\section{RESULTS}

Of a total of 37 patients considered, three patients with uncontrolled diabetes mellitus and two patients with pulmonary tuberculosis were excluded. A total of 32 patients were included in this study. There were 26 females and six males, with ages ranging from 17 to 69 years. These patients were randomly allocated into two groups of 16 each: the guava leaves mouthwash treatment group $(\mathrm{N}=16)$ and isotonic sodium chloride solution control group $(\mathrm{N}=16)$. All participants completed the study. No adverse effects were recorded although one participant in the treatment group complained of nausea attributed to laryngopharyngeal reflux. There was no significant difference between the two groups in terms of demographic characteristics of age and sex with all $p$ values $>0.05$ (Table 1 ).

Table 1. Comparison of demographic characteristics between the two groups

\begin{tabular}{|l|l|l|l|}
\hline & $\begin{array}{l}\text { NSS } \\
(n=16)\end{array}$ & $\begin{array}{l}\text { Guava } \\
(n=16)\end{array}$ & P value \\
\hline$\frac{\text { Age in years }}{\text { Mean } \pm \text { SD }}$ & $44.06 \pm 15.24$ & $39.40 \pm 12.30$ & $0.34(\mathrm{NS})$ \\
\hline$\underline{\text { Sex }}$ & $15(93.8 \%)$ & $11(68.8 \%)$ & $0.17(\mathrm{NS})$ \\
Female & $1(6.2 \%)$ & $5(31.2 \%)$ & \\
Male & $(12 \%)$ \\
\hline
\end{tabular}

There was no significant difference in VAS scores of both groups on Days 1 and 2 ( $p=0.78$ and 0.32 respectively). However, there was a significant difference in VAS scores of both groups from Day 3 until Day 7 (all $p$ values $<0.05$ ). The VAS scores of those given guava mouthwash 
were significantly lower than those given NSS (Table 2). Comparison of the differences in VAS scores at different intervals between the two groups showed that there was a significant difference from Days 3 to 7 (all $p$ values $<0.05$ ). The decrease in VAS scores of those given guava was significantly greater than those given NSS (Table 3). The mean VAS scores

Table 2. Comparison of VAS Scores at different intervals between the two groups

\begin{tabular}{|c|c|c|c|}
\hline & $\begin{array}{l}\text { NSS } \\
(n=16)\end{array}$ & $\begin{array}{l}\text { Guava } \\
(n=16)\end{array}$ & P value \\
\hline $\begin{array}{l}\text { Day } 1 \\
\text { Mean } \pm \text { SD }\end{array}$ & $5.62 \pm 1.36$ & $5.50 \pm 1.26$ & 0.78 (NS) \\
\hline $\begin{array}{l}\text { Day } 2 \\
\text { Mean } \pm \text { SD }\end{array}$ & $5.44 \pm 1.41$ & $4.88 \pm 1.74$ & 0.32 (NS) \\
\hline $\begin{array}{l}\text { Day } 3 \\
\text { Mean } \pm \text { SD }\end{array}$ & $4.75 \pm 1.00$ & $3.62 \pm 1.58$ & $0.02(\mathrm{~S})$ \\
\hline $\begin{array}{l}\text { Day 4 } \\
\text { Mean } \pm \text { SD }\end{array}$ & $3.94 \pm 1.34$ & $2.31 \pm 1.74$ & $0.005(\mathrm{~S})$ \\
\hline $\begin{array}{l}\text { Day } 5 \\
\text { Mean } \pm \text { SD }\end{array}$ & $3.18 \pm 1.38$ & $1.31 \pm 1.30$ & $0.0004(S)$ \\
\hline $\begin{array}{l}\text { Day } 6 \\
\text { Mean } \pm \text { SD }\end{array}$ & $3.12 \pm 1.36(3)$ & $0.38 \pm 0.72(0)$ & $<0.0001$ (S) \\
\hline $\begin{array}{l}\text { Day } 7 \\
\text { Mean } \pm \text { SD }\end{array}$ & $2.68 \pm 1.14(3)$ & $0.31 \pm 0.60(0)$ & $<0.0001(\mathrm{~S})$ \\
\hline
\end{tabular}

Table 3. Comparison of the differences (decrease) in VAS scores at different intervals between the two groups

\begin{tabular}{|c|c|c|c|}
\hline Difference & $\begin{array}{l}\text { NSS } \\
(n=16)\end{array}$ & $\begin{array}{l}\text { Guava } \\
(n=16)\end{array}$ & P value \\
\hline $\begin{array}{l}\text { Day } 1 \text { vs Day } 2 \\
\text { Mean } \pm \text { SD }\end{array}$ & $0.18 \pm 0.54(0)$ & $0.62 \pm 1.02(0)$ & 0.17 (NS) \\
\hline $\begin{array}{l}\text { Day } 1 \text { vs Day } 3 \\
\text { Mean } \pm \text { SD }\end{array}$ & $0.88 \pm 0.96$ & $1.88 \pm 1.36$ & $0.02(\mathrm{~S})$ \\
\hline $\begin{array}{l}\text { Day } 1 \text { vs Day } 4 \\
\text { Mean } \pm \text { SD }\end{array}$ & $1.68 \pm 1.44$ & $3.18 \pm 1.94$ & $0.01(\mathrm{~S})$ \\
\hline $\begin{array}{l}\text { Day } 1 \text { vs Day } 5 \\
\text { Mean } \pm \text { SD }\end{array}$ & $2.44 \pm 1.26$ & $4.18 \pm 1.68$ & $0.002(\mathrm{~S})$ \\
\hline $\begin{array}{l}\text { Day } 1 \text { vs Day } 4 \\
\text { Mean } \pm \text { SD }\end{array}$ & $1.68 \pm 1.44$ & $3.18 \pm 1.94$ & $0.01(S)$ \\
\hline $\begin{array}{l}\text { Day } 1 \text { vs Day } 6 \\
\text { Mean } \pm \text { SD }\end{array}$ & $2.50 \pm 1.03$ & $5.12 \pm 1.31$ & $<0.00001(\mathrm{~S})$ \\
\hline $\begin{array}{l}\text { Day } 1 \text { vs Day } 7 \\
\text { Mean } \pm \text { SD }\end{array}$ & $2.94 \pm 1.18$ & $5.18 \pm 1.16$ & $<0.00001(\mathrm{~S})$ \\
\hline
\end{tabular}

at different intervals between the two groups are presented graphically in (Figure 2). There was a statistically significant, marked improvement of pain symptoms as early as three days post-treatment in the guava leaves mouthwash group as compared to the isotonic sodium chloride solution mouthwash group.

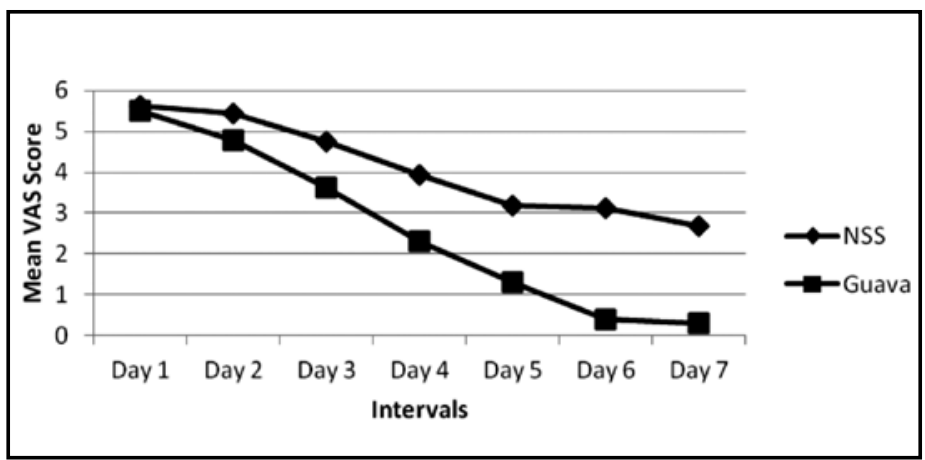

Figure 2. Mean VAS scores at different intervals between the two groups

The comparison of ulcer sizes between the two groups showed no significant difference on day $1(p=0.80)$. On the other hand, there was a significant difference noted in size on day $7(p=0.004)$. The mean size of ulcers in those given guava mouthwash was significantly smaller than those given NSS with a mean of $0.25 \mathrm{~mm}$ and $0.75 \mathrm{~mm}$ respectively (Table 4). There was a significant size difference between the two groups $(p=0.03)$. The decrease in size of those given guava mouthwash was significantly greater than those given NSS with a mean decrease in size of $1.44 \mathrm{~mm}$ and $0.88 \mathrm{~mm}$ respectively (Table 5). The distribution of subjects according to ulcer size at Days 1 and 7 is presented graphically in (Figure 3). There was a statistically significant,

Table 4. Comparison of ulcer size at Days 1 and 7 between the two groups

\begin{tabular}{|c|c|c|c|}
\hline & $\begin{array}{l}\text { NSS } \\
(n=16)\end{array}$ & $\begin{array}{l}\text { Guava } \\
(n=16)\end{array}$ & P value \\
\hline Day 1 & & & \\
\hline $1 \mathrm{~mm}$ & $9(56.2 \%)$ & $\underline{6(37.5 \%)}$ & \\
\hline$\underline{2 \mathrm{~mm}}$ & $\underline{4(25.0 \%)}$ & $9(56.2 \%)$ & \\
\hline$\underline{3 \mathrm{~mm}}$ & $\underline{3(18.8 \%)}$ & $1(6.3 \%)$ & \\
\hline Mean \pm SD & $1.62 \pm 0.80$ & $\underline{1.69 \pm 0.60}$ & 0.80 (NS) \\
\hline Day 7 & & & \\
\hline$\underline{0 \mathrm{~mm}}$ & $4(25.0 \%)$ & $12(75.0 \%)$ & \\
\hline$\underline{1 \mathrm{~mm}}$ & $\underline{12(75.0 \%)}$ & $4(25.0 \%)$ & \\
\hline Mean \pm SD & $0.75 \pm 0.45$ & $\underline{0.25 \pm 0.45}$ & $0.004(S)$ \\
\hline
\end{tabular}




\section{ORIGINAL ARTICLES}

Table 5. Comparison of ulcer size difference between the two groups
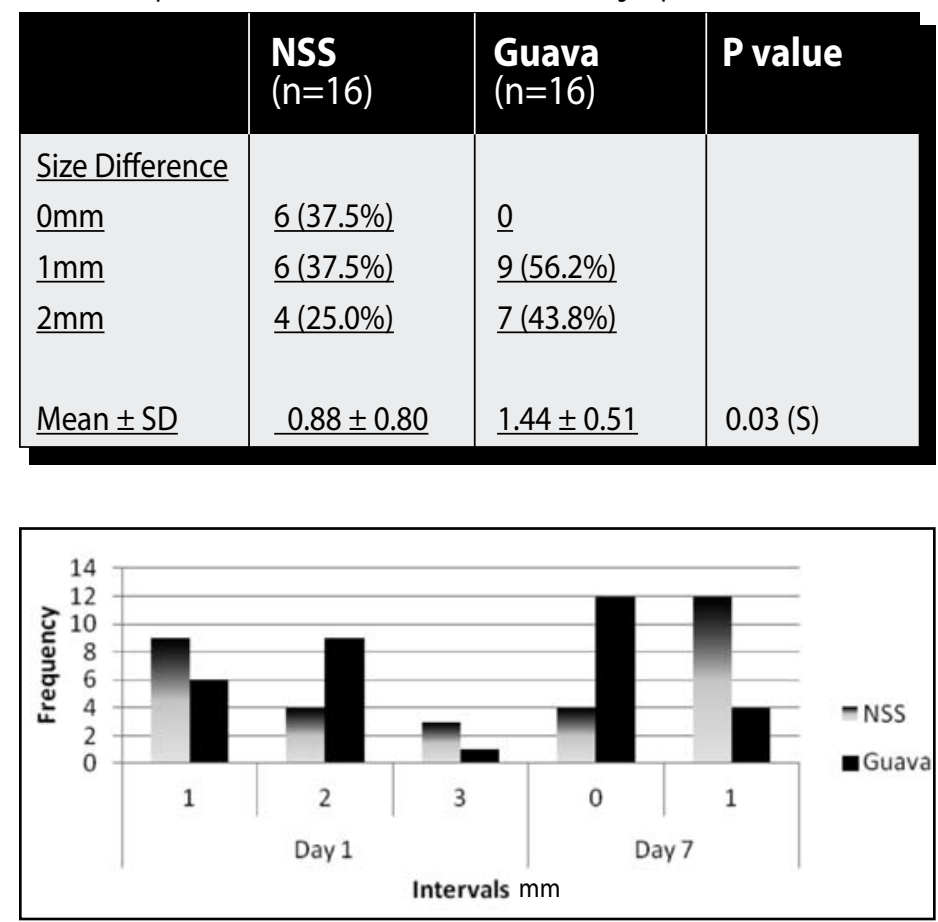

Figure 3. Distribution of subjects according to size at day 1 and day 7 between the 2 groups

markedly faster resolution of aphthous ulcer size in the guava leaves mouthwash group as compared to the isotonic sodium chloride solution mouthwash group.

The results obtained suggest that guava leaves mouthwash is effective as an alternative treatment for aphthous ulcers.

\section{DISCUSSION}

P. guajava has been known to have antimicrobial, ${ }^{9}$ antiinflammatory, ${ }^{10}$ antitumor, ${ }^{11}$ antiallergic, ${ }^{12}$ antihyperglycemic, ${ }^{10,13}$ and antimutagenic ${ }^{14}$ activities. It has been used to treat wounds, ${ }^{15}$ cough $^{3}$ and dental diseases. ${ }^{16}$ Flavonoids extracted from guava leaves including morin-3-O-lyxoside, morin-3-0-arabinoside, quercetin and quercetin-3O-arabinoside were reported to have strong antibacterial action. ${ }^{9} \mathrm{An}$ in vitro study of aqueous extract of Psidium guajava reduced the cellsurface hydrophobicity of Strep. sanguinis, Strep. mitis and Actinomyces sp. responsible in development of dental plaques. ${ }^{16}$ Psidium guajava also has been used for the management of various diseases like toothache, sore throat, inflamed gums, and a number of other conditions. ${ }^{3}$ Growth of Staphylococcus aureus and beta-streptococcus group A, as determined by the disc diffusion method, was inhibited by extract of dry guava leaves. ${ }^{3}$ The anti-inflammatory and analgesic properties of the plant's leaf extract were determined by using experimental animals. Diclofenac and morphine were used as standard reference for comparison..$^{10}$ The numerous tannins, polyphenolic compounds, flavonoids, ellagic acid, triterpenoids, guiajaverin, quercetin and other chemical compounds present in the plant account for the observed anti-inflammatory and analgesic effects of the plant's leaf extract. ${ }^{10}$ Much of the traditional uses of $P$. guajava have been validated by scientific research. Toxicity studies in mice and other animal models as well as controlled human studies show both leaf and fruit are safe without any side effects. ${ }^{17}$

The effectivity of guava leaves in pain alleviation may largely be due to the numerous flavonoids, tannins, polyphenolic compounds, ellagic acid, triterpenoids, guiajaverin, quercetin and other chemical compounds present in the plant. ${ }^{10}$ Flavonoids inhibit biosynthesis of prostaglandins, which are involved in various immunologic responses and are the end products of the cyclooxygenase and lipoxygenase pathways. ${ }^{18}$ Protein kinases are another class of regulatory enzymes affected by flavonoids. Inhibition of these enzymes provides the mechanism by which flavonoids inhibit inflammatory processes..$^{19}$

Significant decrease in the size of aphthous ulcers may be attributed to the presence of flavonoids extracted from guava leaves including morin-3-O-lyxoside, morin-3-O-arabinoside, quercetin and quercetin3-0-arabinoside which were reported to have strong antibacterial and antiviral action. ${ }^{9}$ Since it is hypothesized that one of the causes of aphthous ulcer is hypersensitivity and inflammation, the resolution of size may be due to the effects of flavonoids.

A significant amount of work has been done on the pharmacological and biological activity and possible application of chemical compounds. The taste and scent of guava are a limiting factor in proper standardization of clinical trials as patients could easily recognize its taste and scent. Hence, VAS was combined with measurement of aphthous ulcer size to more objectively document its therapeutic potential.

Our study showed that guava leaves mouthwash, compared to isotonic saline solution, was effective for aphthous ulcers in terms of reduction of symptoms of pain and faster reduction of ulcer size. Further clinical trials comparing this mouthwash against other treatment options are recommended. 
ORIGINAL ARTICLES

\section{REFERENCES}

1. Rattanachaikunsopon P, Phumkhachorn P. Contents and antibacterial activity of flavonoids extracted from leaves of Psidium guajava. Journal of Medicinal Plants Research. 2010; 4(5): 393396.

2. Quisumbing E. Medicinal Plants of the Philippines. Katha Publishing Company. JMC Press, Quezon City, Philippines. 1978

3. Jaiarj P, Khoohaswan P, Wongkrajang Y, Peungvicha P, Suriyawong P, Saraya ML et al. Anticough and antimicrobial activities of Psidium guajava Linn. Leaf extract. J Ethnopharmacol. 1999 Nov 1; 67(2): 203-212.

4. Scully C. Clinical Practice. Aphthous Ulceration. N Engl J Med. 2006 Jul 13; 355(2):165-172.

5. Thornhill MH, Baccaglini L, Theaker E, Pemberton MN. A Randomized, double-blind, placebocontrolled trial of pentoxifylline for the treatment of recurrent aphthous stomatitis. Arch Dermatol. 2007 Apr; 143(4):463-470.

6. Chattopadhyay A, Shetty KV. Recurrent aphthous stomatitis. Otolaryngol Clin North Am. 2011 Feb; 44(1): 79-88.

7. Barrons RW. Treatment strategies for recurrent oral aphthous ulcers. Am J Health Syst

Pharm. 2001 Jan 1; 58(1):41-53.

8. Thomas M, Del Mar C, Glasziou P. How effective are treatments other than antibiotics for acute sore throat? Br J Gen Pract. 2000 Oct; 50(459):817-820.

9. Arima H, Danno G. Isolation of antimicrobial compounds from guava (Psidium guajava L.). Biosci. Biotechnol. Biochem. 2002 Aug; 66(8): 1727-1730.

10. Ojewole JA. Antiinflammatory and analgesic effects of Psidium guajava Linn. (Myrtaceae) leaf aqueous extract in rats and mice. Methods Find Exp Clin Pharmacol. 2006 Sep; 28(7):441-6.

11. Manosroi J, Dhumtanom P, Manosroi A. Anti-proliferative activity of essential oil extracted from Thai medicinal plants on KB and P388 cell lines. Cancer Lett. 2006 Apr 8. 235(1): 114-120.

12. Tona L, Kambu K, Ngimbi N, Cimanga K, Vlietinck AJ.. Antiamoebic and phytochemical screening of some Congolese medicinal plants. J Ethnopharmacol.1998 May; 61(1): 57-65.

13. Mukhtar HM, Ansari SH, Bhat ZA, Naved T, Singh P. Antidiabetic activity of an ethanol extract obtained from the stem bark of Psidium guajava (Myrtaceae). Pharmazie. 2006 Aug; 61(8): 725 727.

14. Grover IS, Bala S. Studies on antimutagenic effect of guava (Psidium guajava) in Salmonella typhimurium. Mutat Res. 1993 Jun; 300(1): 1-3.

15. Chah KF, Eze CA, Emuelosi CE, Esimone CO. Antibacterial and wound healing properties of methanolic extracts of some Nigerian medicinal plants. JEthnopharmacol. 2006 Mar 8; 104(1-2): 164-167.

16. Razak FA, Othman RY, Rahim ZH. The effect of Piper betle and Psidium guajava extracts on the cell-surface hydrophobicity of selected early settlers of dental plaque. J Oral Sci. 2006 Jun 48(2): 71-75.

17. Kamath JV, Rahul N, Ashok Kumar CK, Lakshmi SM. Psidium guajava: A review. Int J Green Pharm $2008 ; 2: 9-12$.

18. Moroney MA, Alcaraz MJ, Forder RA, Carey F, Hoult JR. Selectivity of neutrophil 5-lipoxygenase and cyclooxygenase inhibition by anti- inflammatory flavonoid glycoside and related aglycone flavonoids. J Pharm Phamocol. 1988 Nov; 40(11): 787-92.

19. Manthey JA, Grohmann K, Guthrie N. Biological properties of citrus flavonoids pertaining to cancer and inflammation. Curr Med Chem. 2001 Feb; 8(2): 135-153. 